\title{
Personal View: Should haemoglobin A1C be used for diagnosis of diabetes mellitus in Malawi?
}

\author{
WP Nakanga, A Crampin, M Nyirenda
}

Malawi Epidemiology and Intervention Research Unit (MEIRU), Lilongwe, Malawi

Correspondence to: Wisdom P. Nakanga | E-mail: wisdomnakanga@gmail.com

\section{Introduction}

Glycated haemoglobin (haemoglobin A1c or HbA1c) level has long been utilised for assessment of long-term glycaemic control in patients with diabetes mellitus. ${ }^{1}$ More recently it has also been included as a criterion for the diagnosis of type 2 diabetes mellitus. ${ }^{2}$ However, use of $\mathrm{HbA} 1 \mathrm{c}$ as a diagnostic tool for diabetes is controversial. ${ }^{3}$ This article discusses some of the limitations, and explores whether HbA1c should be recommended for diagnosis of diabetes mellitus in Malawi and similar settings.

\section{HbAlc formation and structure}

$\mathrm{HbA1c}$ is modified haemoglobin, with a glucose linked to the N-terminal valine of the beta chain. ${ }^{4} \mathrm{It}$ is made in vivo by the non-enzymatic attachment of glucose to haemoglobin. ${ }^{5}$ This occurs first by formation of a labile adduct aldimine, which is a Schiff base, that then rearranges to form a more stable ketoamine (Figure 1). ${ }^{6}$ The rate at which this reaction occurs is related to the prevailing glucose concentration, and it is expressed as a percentage of the total haemoglobin.

Figure 1: Formation of glycated haemoglobin (HbAlc)

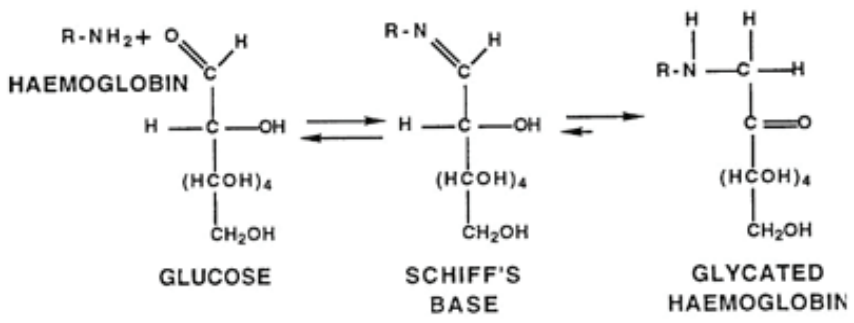

\section{HbA1c in monitoring diabetes control}

The potential utility of $\mathrm{HbA} 1 \mathrm{c}$ in management of diabetes was proposed in 1976 by Ronald Koenig and Anthony Cerami $^{8}$; and a 1985 World Health Organization (WHO) report recommended its use for practical assessment of longterm glycaemic control in patients with diabetes mellitus. ${ }^{1}$ In individuals with a normal red blood cell lifespan, the level of $\mathrm{HbA} 1 \mathrm{c}$ is related to the circulating plasma levels of glucose, as well as the average glycaemia of the previous 12 to 16 weeks, as this is the half-life of red blood cells. ${ }^{6} \mathrm{HbA1c}$ is considered the gold-standard biochemical indicator of long-term glycaemic control in diabetic patients, ${ }^{10}$ as a good association has been demonstrated with the chronic microvascular complications of diabetes, such as retinopathy, nephropathy and neuropathy. ${ }^{2,11} \mathrm{HbA} 1 \mathrm{c}$ of less than $6.0 \%$ is considered normal, $6.0 \%$ to $7.5 \%$ is good control of diabetes mellitus, $7.6 \%$ to $9.0 \%$ is considered unsatisfactory control, and $\mathrm{HbA} 1 \mathrm{c}$ of more than $9.0 \%$ is regarded as very poor control of diabetes mellitus. In Blantyre, Malawi, Cohen et al., in a survey of the management, control, and complications of diabetes mellitus in patients attending a diabetes clinic, found that $74 \%$ of patients had unsatisfactory levels of HbA1c (greater than 7.5\%), and this was accompanied by a high frequency of microvascular complications. ${ }^{12}$

\section{HbA1c and diabetes diagnosis}

The diagnosis of diabetes has traditionally been based upon the detection of elevated plasma glucose levels, either after fasting, two hours after an oral glucose $(75 \mathrm{~g})$ tolerance test (OGTT), or, in symptomatic individuals, after a random blood glucose check. ${ }^{13}$ Recently, the American Diabetes Association and the WHO have recommended using $\mathrm{HbA} 1 \mathrm{c}$ (greater than or equal to $6.5 \%$ ) to diagnose diabetes mellitus. ${ }^{14}$ This was based, in part, on the ability for HbA1c to predict clinical outcomes. It has been established that HbA1c has a similar relationship with prevalent diabetic retinopathy as that of both fasting and two-hour plasma glucose levels, and that lowering $\mathrm{HbAlc}$ can reduce microvascular complications. ${ }^{15,16}$ Although HbA1c testing is currently more expensive than blood glucose measurements (the net cost of an HbA1c test is, on average, 13.6 times higher than a plasma glucose measurement ${ }^{3}$, it provides significant practical advantages. $\mathrm{HbA1c}$ testing can be performed at any time of the day and does not require any special pre-test preparation by the patient (for example, overnight fasting or glucose loading). ${ }^{17,18}$ While the use of HbA1c for long-term glycaemic control is well accepted, there remains significant controversy on its use as a diagnostic tool, and many studies show significant discordance between fasting glucose and HbA1c tests. ${ }^{19}$

\section{Factors affecting HbA1c levels}

There are many common factors, including genetic and medical conditions, that influence $\mathrm{HbA} 1 \mathrm{c}$ and its measurement, even when glucose levels are constant. ${ }^{20,21}$ Several studies have shown that in recent-onset, drug-naïve type 2 diabetes (controlling for age, sex and BMI), there is ethnic variability of $\mathrm{HbA} 1 \mathrm{c}$, despite similar fasting plasma glucose levels and similar or lower post-glucose load glucose levels. ${ }^{22,23}$ People of African descent and South Asians appear to have significantly higher levels of HbA1c (and therefore levels "diagnostic" of diabetes) across the full spectrum of glycaemia, ${ }^{21}$ compared to Caucasians. ${ }^{24-26}$ The optimal $\mathrm{HbA1c}$ threshold for detecting diabetes may thus vary by ethnic group ${ }^{27}$; while the $\mathrm{WHO}$ currently recommends a diagnostic HbA1c of $6.5 \%$, other studies have shown that in some races a lower threshold of $6.3 \%$ can be used for detecting diabetes in high-risk populations. ${ }^{28}$

In addition to the ethnic limitations described above, a number of other disorders influence $\mathrm{HbA1c}$, and their frequencies will depend on the setting. Conditions that alter red cell lifespan alter the Hb1Ac concentrations, with conditions that shorten red cell survival, such as haemolysis, decreasing $\mathrm{HbA} 1 \mathrm{c}$, and those disease states that prolong red cell survival increasing $\mathrm{HbA} 1 \mathrm{c},{ }^{29}$ owing to the change in the duration of contact of the red blood cells with glucose in the blood. Thus, decreased erythropoiesis caused by iron or vitamin deficiency may cause increased $\mathrm{HbA1c}$; and increased erythropoiesis caused by haemolysis (for example, in malaria), administration of erythropoietin, iron, vitamin B12, and MMJ VOL 28 (1): March 2016 
reticulocytosis, will lead to its decrease. Decreased lifespan of red blood cells resulting from haemoglobinopathies, splenomegaly (also common in malaria) rheumatoid arthritis, or drugs (for example, antimicrobials such as ribavirin and dapsone) can also decrease HbA1c.

\begin{tabular}{|c|c|c|}
\hline Factor influencing HbAlc & Increased HbAlc & Decreased HbA1c \\
\hline Erythropoiesis & $\begin{array}{l}\text { Iron deficiency, vitamin B12 } \\
\text { deficiency, decreased } \\
\text { erythropoiesis }\end{array}$ & $\begin{array}{l}\text { Administration of } \\
\text { erythropoietin, iron or vitamin } \\
\text { B12, chronic liver disease }\end{array}$ \\
\hline Erythrocyte destruction & $\begin{array}{l}\text { Increased erythrocyte lifespan, } \\
\text { splenectomy }\end{array}$ & $\begin{array}{l}\text { Decreased erythrocyte lifespan, } \\
\text { haemoglobinopathies, malaria, } \\
\text { splenomegaly, rheumatoid } \\
\text { arthritis, drugs (e.g., } \\
\text { antiretrovirals, ribavirin, } \\
\text { dapsone) }\end{array}$ \\
\hline Glycation & $\begin{array}{l}\text { Alcoholism, chronic renal failure, } \\
\text { decreased erythrocyte } \mathrm{pH}\end{array}$ & $\begin{array}{l}\text { Ingestion of aspirin, vitamin C, } \\
\text { vitamin E, increased erythrocyte } \\
\mathrm{pH}\end{array}$ \\
\hline Assays & $\begin{array}{l}\text { Hyperbilirubinaemia, } \\
\text { carbamylated haemoglobin, } \\
\text { alcoholism, large doses of aspirin }\end{array}$ & Hypertriglyceridaemia \\
\hline
\end{tabular}

Modified from Gallagher et al. ${ }^{17}$

The relationship between HbA1c and HIV infection is also complex. Slama et al. found that at a fasting glucose of 125 $\mathrm{mg} / \mathrm{dL}$, median $\mathrm{HbA} 1 \mathrm{c}$ values were $0.21 \%$ lower in HIVinfected men than in HIV-uninfected men, and that the magnitude of this difference increased at higher glucose values. $^{30}$

They also found that $\mathrm{HbA1C}$ discordance was associated with lower CD4 cell counts; high mean corpuscular volume (MCV); high mean corpuscular haemoglobin $(\mathrm{MCH})$; and a regimen containing a protease inhibitor, a non-nucleoside reverse transcriptase inhibitor, and zidovudine. ${ }^{30}$ The use of HbA1c could therefore lead to underdiagnosis or undertreatment of established diabetes mellitus, particularly in HIV-positive people on antiretroviral therapy (ART), or those with advanced disease. ${ }^{30}$ This is significant since HIV and AIDS may have an impact on glucose metabolism, and there are an increasing number of people in Malawi who are dually affected by HIV and diabetes. ${ }^{31}$

Finally, HbA1c testing (whether laboratory analysis or pointof-care) requires a rigorous programme to standardise the assays, ${ }^{32}$ which may not be possible in many developing countries. Lack of standardisation would lead to a high degree of uncertainty with the results generated in these settings. ${ }^{3}$

\section{Conclusions}

HbA1c is a useful addition to the tools available to diagnose diabetes, and it has clear advantages. However, challenges including cost, assay standardization and multiple potential confounding conditions must be considered. Individual countries will therefore need to decide whether HbA1c as a diagnostic tool is appropriate in relation to prevailing circumstances. Malawi is resource-poor and has a high prevalence of conditions that can influence the performance of HbA1c (such as HIV, anaemia of various aetiologies, and disorders associated with increased red cell turnover, including malaria). It would therefore be premature to advocate the use of HbA1c to diagnose diabetes mellitus in Malawi. More research will be required to fully understand the utility of $\mathrm{HbA1c}$ and its limitations in the diagnosis of diabetes in Malawi and sub-Saharan Africa in general.

\section{References}

1. Osei K, Rhinesmith S, Gaillard T, Schuster D. Is glycosylated hemoglobin A1c a surrogate for metabolic syndrome in nondiabetic, first-degree relatives of African-American patients with type 2 diabetes? J Clin Endocrinol Metab. 2003 Oct;88(10):4596-601.

2. O Ekpebegh C, Longo-Mbenza B, Blanco-Blanco E. Glycosylated haemoglobin is markedly elevated in new and known diabetes patients with hyperglycaemic ketoacidosis. Afr Health Sci. 2014 Sep;14(3):52632. doi: 10.4314/ahs.v14i3.5.

3. Gomez-Perez FJ, Aguilar-Salinas CA, Almeda-Valdes P, CuevasRamos D, Lerman Garber I, Rull JA. HbA1c for the diagnosis of diabetes mellitus in a developing country. A position article. Arch Med Res. 2010 May;41(4):302-8. doi: 10.1016/j.arcmed.2010.05.007.

4. Longo-Mbenza B,Muaka MM, Mbenza G, Mbungu-Fuele S, MabwaMbalanda L, Nzuzi-Babeki V, et al. Risk factors of poor control of HBA1c and diabetic retinopathy: paradox with insulin therapy and high values of HDL in African diabetic patients. International Journal of Diabetes \& Metabolism. 2008 Aug;16(2): 69-78.

5. Woerle HJ, Neumann C, Zschau S, Tenner S, Irsigler A, Schirra J, et al. Impact of fasting and postprandial glycemia on overall glycemic control in type 2 diabetes Importance of postprandial glycemia to achieve target HbA1c levels. Diabetes Res Clin Pract. 2007 Aug;77(2):280-5.

6. Bhavna N, Raghuveer C, Niveditha S, Manjunatha Goud BK, Sarsina Devi O, Devaki RN. Glycated hemoglobin - the clinical and biochemical divide: a review. International Journal of Pharmaceutical Sciences Review and Research. 2011 Jan-Feb; 6(2):121-4.

7. Kumar P, Clark M, editors. Kumar \& Clark's Clinical Medicine. 8th ed. Edinburgh: Saunders Elsevier; 2012.

8. Koenig RJ, Peterson CM, Jones RL, Saudek C, Lehrman M, Cerami A. Correlation of glucose regulation and hemoglobin A1c in diabetes mellitus. N Engl J Med. 1976 Aug 19;295(8):417-20.

9. Edo AE, Akhuemokhan K. Relationships between hemoglobin A $1 \mathrm{c}$ and spot glucose measurements in Nigerians with type 2 diabetes mellitus. Niger J Clin Pract. 2012 Jan-Mar;15(1):23-6. doi: 10.4103/1119-3077.94091.

10. Matheka DM, Kilonzo JM, Munguti CM, Mwangi PW. Pattern, knowledge and practices of $\mathrm{HbA} 1 \mathrm{C}$ testing among diabetic patients in a Kenyan tertiary referral hospital. Global Health. 2013 Nov 5;9:55. doi: 10.1186/1744-8603-9-55.

11. Kilpatrick ES, Atkin SL. Using haemoglobin A(1c) to diagnose type 2 diabetes or to identify people at high risk of diabetes. BMJ. $2014 \mathrm{Apr}$ 25;348:g2867. doi: 10.1136/bmj.g2867.

12. Cohen DB, Allain TJ, Glover S, Chimbayo D, Dzamalala H, Hofland HW, et al. A survey of the management, control, and complications of diabetes mellitus in patients attending a diabetes clinic in Blantyre, Malawi, an area of high HIV prevalence. Am J Trop Med Hyg. 2010 Sep;83(3):575-81. doi: 10.4269/ajtmh.2010.10-0104.

13. American Diabetes Association. Diagnosis and classification of diabetes mellitus. Diabetes Care. 2010 Jan;33 Suppl 1:S62-9. doi: $10.2337 / \mathrm{dc} 10-\mathrm{S} 062$.

14. International Expert Committee: Nathan DM, Balkau B, Bonora E, Borch-Johnson K, Buse JB, Colagiuri S. International Expert Committee report on the role of the A1C assay in the diagnosis of diabetes. Diabetes Care. 2009 Jul;32(7):1327-34. doi: 10.2337/dc09-9033.

15. Bower JK, Brancati FL, Selvin E. No ethnic differences in the association of glycated hemoglobin with retinopathy: the national health and nutrition examination survey 2005-2008. Diabetes Care. 2013 Mar;36(3):569-73. doi: 10.2337/dc12-0404. 
16. Colagiuri S, Lee CM, Wong TY, Balkau B, Shaw JE, Borch-Johnsen K; DETECT-2 Collaboration Writing Group. Glycemic thresholds for diabetes-specific retinopathy: implications for diagnostic criteria for diabetes. Diabetes Care. 2011 Jan;34(1):145-50. doi: 10.2337/dc101206.

17. Gallagher EJ, Le Roith D, Bloomgarden Z. Review of hemoglobin $\mathrm{A}(1 \mathrm{c})$ in the management of diabetes. J Diabetes. 2009 Mar;1(1):9-17. doi: 10.1111/j.1753-0407.2009.00009.x.

18. Kilpatrick ES, Bloomgarden ZT, Zimmet PZ. Is haemoglobin A1c a step forward for diagnosing diabetes? BMJ. 2009 Nov 10;339:b4432. doi: 10.1136/bmj.b4432.

19. Zhou XH, Ji LN, Luo YY, Zhang XY, Han XY, Qiao Q. Performance of $\mathrm{HbA}(1 \mathrm{c})$ for detecting newly diagnosed diabetes and pre-diabetes in Chinese communities living in Beijing. Diabet Med. 2009 Dec;26(12):1262-8. doi: 10.1111/j.1464-5491.2009.02831.x.

20. Pani LN, Korenda L, Meigs JB, Driver C, Chamany S, Fox CS, et al. Effect of aging on A1C levels in individuals without diabetes: evidence from the Framingham Offspring Study and the National Health and Nutrition Examination Survey 2001-2004. Diabetes Care. 2008 Oct;31(10):1991-6. doi: 10.2337/dc08-0577.

21. Herman WH, Ma Y, Uwaifo G, Haffner S, Kahn SE, Horton ES, et al. Differences in $\mathrm{A} 1 \mathrm{C}$ by race and ethnicity among patients with impaired glucose tolerance in the Diabetes Prevention Program. Diabetes Care. 2007 Oct;30(10):2453-7.

22. Herman WH. Do race and ethnicity impact hemoglobin A1c independent of glycemia? J Diabetes Sci Technol. 2009 Jul 1;3(4):65660

23. Grimsby JL, Porneala BC, Vassy JL, Yang Q, Florez JC, Dupuis $\mathrm{J}$, et al. Race-ethnic differences in the association of genetic loci with HbA1c levels and mortality in U.S. adults: the third National Health and Nutrition Examination Survey (NHANES III). BMC Med Genet. 2012 Apr 27;13:30

24. Mostafa SA, Davies MJ, Webb D, Gray LJ, Srinivasan BT, Jarvis $\mathrm{J}$, et al. The potential impact of using glycated haemoglobin as the preferred diagnostic tool for detecting Type 2 diabetes mellitus. Diabet Med. 2010 Jul;27(7):762-9. doi: 10.1111/j.1464-5491.2010.03015.x.
25. Carson AP, Reynolds K, Fonseca VA, Muntner P. Comparison of A1C and fasting glucose criteria to diagnose diabetes among U.S. adults. Diabetes Care. 2010 Jan;33(1):95-7. doi: 10.2337/dc09-1227.

26. Kumar PR, Bhansali A, Ravikiran M, Bhansali S, Dutta P, Thakur JS, et al. Utility of glycated hemoglobin in diagnosing type 2 diabetes mellitus: a community-based study. J Clin Endocrinol Metab. 2010 Jun;95(6):2832-5. doi: 10.1210/jc.2009-2433.

27. Rohlfing CL, Little RR, Wiedmeyer HM, England JD, Madsen R, Harris MI, et al. Use of GHb (HbAlc) in screening for undiagnosed diabetes in the U.S. population. Diabetes Care. 2000 Feb;23(2):187-91.

28. Bao Y, Ma X, Li H, Zhou M, Hu C, Wu H, et al.,Glycated haemoglobin A1c for diagnosing diabetes in Chinese population: cross sectional epidemiological survey. BMJ. 2010 May 17;340:c2249. doi: 10.1136/bmj.c2249.

29. Cohen RM, Franco RS, Khera PK, Smith EP, Lindsell CJ, Ciraolo $\mathrm{PJ}$, et al. Red cell life span heterogeneity in hematologically normal people is sufficient to alter HbA1c. Blood. 2008 Nov 15;112(10):428491. doi: 10.1182/blood-2008-04-154112.

30. Slama L, Palella FJ Jr, Abraham AG, Li X, Vigouroux C, Pialoux $\mathrm{G}$, et al. Inaccuracy of haemoglobin Alc among HIV-infected men: effects of CD4 cell count, antiretroviral therapies and haematological parameters. J Antimicrob Chemother. 2014 Dec;69(12):3360-7. doi: $10.1093 / \mathrm{jac} / \mathrm{dku} 295$.

31. Assayed AA, Muula AS, Nyirenda MJ. The quality of care of diabetic patients in rural Malawi: a case of Mangochi district. Malawi Med J. 2014 Dec;26(4):109-14.

32. Little RR. Glycated hemoglobin standardization--National Glycohemoglobin Standardization Program (NGSP) perspective. Clin Chem Lab Med. 2003 Sep;41(9):1191-8. 